\title{
Regime Type and International Commercial Agreements
}

\author{
B. Peter Rosendorff* and Kongjoo Shin ${ }^{\dagger}$ \\ New York University
}

August 2014

\begin{abstract}
Preferential Trade Agreements (PTAs) and Bilateral Investment Treaties (BITs) limit memberstates' policy discretion; consequently policy uncertainty is mitigated. Reductions in policy uncertainty stemming from accession to an International Agreement (IA) improves the resource allocation decisions of the voters and reduces deadweight losses from the need to self-insure against policy uncertainty. If electoral accountability makes expropriation of assets or discriminatory treatment of firms more costly to leaders (whereas electoral accountability has little effect on rent creation via tariff revenues) then among developing countries, democratic states sign PTAs relatively more frequently than autocratic states; however autocratic states are more likely to sign BITs than are democratic states. We offer a simple model, and present some empirical regularities consistent with the theory.
\end{abstract}

*Professor, Department of Politics, New York University, New York NY 10012, peter.rosendorff@nyu.edu.

${ }^{\dagger}$ Doctoral candidate, Department of Politics, New York University, New York, NY 10012, and Researcher, National Tohoku University, Sendai, Japan.

Paper written for the International Conference on Market Quality, Trade and Dynamics, in celebration of Professor Makoto Yano's 60th Birthday, at the Institute of Economic Research, Kyoto University, 9 April 2013 
International agreements govern most of the flows of goods and investment capital across international borders. These agreements have the force of international law, and almost always are implemented in domestic law. The importance of these agreements in governing these flows cannot be understated. However, considerable variation exists in across countries in their willingness to forge these agreements and bring them to successful negotiation and accession.

We argue here that political regime type matters for a state's willingness to engage in international commercial cooperation. More significantly, the effect of regime type is conditional on the type of commercial agreements. Democracies are likely to sign and join preferential trade agreements (PTAs) more frequently than autocracies; but the opposite is the case for bilateral investment treaties (BITs). Democracies are less likely to form BITs than are non-democracies.

This brief paper will offer a simple model that shows that the effect of democracy differs depending on the scale of rents that are appropriable in the international commercial agreement by the home government. Trade agreements limit the collection of tariff revenues and hence rents that governments can use for political purposes. Investment agreements also reduce opportunities for expropriation or discriminatory taxation. While both types of agreements limit rent creation, we argue here that electoral accountability makes expropriation of assets or discriminatory treatment of firms more costly to leaders, whereas electoral accountability has little effect on rent creation via tariff revenues. If signing a BIT (relative to a PTA) becomes more expensive as a polity becomes more democratic, then democracies will sign fewer BITs and substitute towards PTAs; a more autocratic state will sign more BITs and substitute away from PTAs.

\section{BITs and PTAs: Literature}

PTAs are agreements by states to limit their trade barriers to levels below some agreed "bound" rates, across a number of sectors and industries. A variety of economic and political explanations have been offered for the proliferation of PTAs; we omit them here. ${ }^{1}$ Our emphasis instead is on the domestic political determinants of PTA formation, particularly on the role of a country's regime-type in shaping its incentives to enter a PTA. Borrowing from the democratic peace literature, the literature establishes that democracies fight fewer trade wars with each other and are more cooperative on trade issues generally. Regime type explains the willingness to sign PTAs (Mansfield, Milner and 
Rosendorff 2000, Pahre 2008) and the observed heterogeneity in PTA structure and institutional design (Pevehouse, Hafner-Burton and Zierler 2002). Mansfield, Milner and Rosendorff (2000) for instance suggest that domestic ratification by a protectionist legislature results in more significant bilateral liberalization than occurs in states without a domestic ratification requirement. Milner and Rosendorff $(1996 ; 1997)$ argue that divided government makes the signing of international trade agreements less frequent, but those agreements that are signed bring about greater liberalization than would be the case under unified government. These studies highlight the important role of domestic political and institutional determinants in developing a coherent understanding of PTA formation. Here we explore the effects of PTAs on reducing policy uncertainty, and interacting that effect with domestic political institutions offers an explanation for the observed patterns of PTA accession.

Bilateral investment treaties (BITs) are devices for institution-poor countries to import institutions that are clear and transparent. BITs credibly commit host governments to minimizing arbitrary and capricious policy shifts, punitive tax rates, and outright expropriation, as well as provide clear limits on policy-choices, and predictable procedures for policy changes. Not only do rules governing property rights and tax treatment get adopted, but violations of those rules have consequences at the international level - enhancing the credibility of the government to limit discretionary and arbitrary changes in policy, and thereby encouraging higher levels of investment. To varying degrees, BITs provide a compelling mechanism to credibly import a set of institutions that commit a state not to expropriate, over-regulate, over-tax, or otherwise excessively interfere in the market, and endangers the signatories with "swift, substantial compensation" in the instance of violation. Again, like PTAs, they bring clarity, transparency and a precise set of legal obligations (Salacuse and Sullivan 2005), enforceable, to some degree, in international arenas.

The pattern of accession to BITs has begun to be explored. Elkins, Guzman and Simmons (2006) argue that developing host countries are more likely to sign BITs when their competitors (for international capital) have done so. Allee and Peinhardt (2014) suggest that BIT signing occurs (and states concede more of their sovereignty) in periods of economic distress. In a related piece Rosendorff and Shin (2014) show that polities that are less transparent sign BITs more frequently, while Arias, Hollyer and Rosendorff (2014) establish that the effect of BIT signings on survival in office is larger for autocratic leaders than for democratic leaders. 
This work is to some degree inspired by Yano (1989). Yano offers an insightful exploration of the effect of a potential voluntary export restraint (VER) on the competitive behavior of the firms in the market whose exports are to be restrained. The anticipated VER increases competition between firms for market share, effectively reducing prices and profits even for the import-competing firms. While Yano focuses on the effect of an anticipated international agreement on domestic economic competition, we focus here instead on the effect of domestic political institutions on the emergence of a variety of international agreements.

We first build a simple model predicting the number of PTAs and BITs a leader will endeavor to sign, conditioned by the type of political regime the leader operates within. We will allow the leader to choose simultaneously how many PTAs and how many BITs to sign. The simple, static model generates two claims: one consistent with intuitions: democracies sign more PTAs than autocracies; and one which is somewhat unexpected - that BIT signing declines with democracy. We then offer some empirical evidence consistent with the theoretical claims.

\section{Model}

Let $t=\left(t_{T}, t_{I}\right)$ be a policy pair - perhaps a tariff, or a trade rule or regulation in the context of international trade (the first policy, $t_{T}$ ), and perhaps a tax rate, or investment in infrastructure or a regulation in the context of the domestic investment climate $\left(t_{I}\right)$. We can think of $t$ as the current policy stance of the government. The state of the current policy regime $t$ is known only imperfectly to the voters/consumers in a manner to be made precise below.

\section{Voters}

There is a continuum of voters, indexed $i$ on the real line. Each voter $i$ chooses a vector of actions $a_{i}$, and denote the profile of actions for all voters as $a$. Each voter $i$ has a loss function $u_{i}\left(a_{i}, t\right)=$ $-\sum_{p=T, I}\left(a_{i p}-t_{p}\right)^{2}$. That is, the voters desire to match their actions as closely as possible to match the state of the regulatory environment. For instance if a worker/voter must choose a sector or an industry in which to seek employment, or a capital owner must choose a sector in which to invest, the amount of labor/capital they provide will depend on the expected wage/return on capital, which in turn may depend on the tariff applied to imports in that sector, or the amount of foreign 
capital that is invested in that sector. Or a firm in an industry must adapt its product to match current rules on local content/health and safety, etc., in order to successfully sell its product in the domestic market or in the preferential trading area. Or a firm's domestic profit depends on how much competition from foreign investors it faces.

The voter is imperfectly informed about the policy stance, $t$, that will apply. Each voter receives the same public signals $y=\left(y_{T}, y_{I}\right)$ about the likely policy regime with $y_{p}=t_{p}+\eta_{p}$, where $\eta_{p}$ is distributed normally with mean zero and variance $\sigma_{p}$ for $p=T, I$. We designate $\eta=\left(\eta_{T}, \eta_{I}\right)$. The signals, $y_{T}$ and $y_{I}$ are independently drawn. It will be useful to denote the "precision" of each signal as $\alpha_{p}=\frac{1}{\sigma_{p}}$. In expectation, therefore, the voter prefers signals that are more precise - which maps to the idea above that individual, and hence social, welfare is enhanced by a more stable, or less unpredictable trade or investment policy.

\section{Executive}

Social welfare is the total utility of all voters. $W(a, t)=-\int \sum_{p=T, I}\left(a_{i p}-t_{p}\right)^{2} d i$. The government however cares about survival in office. Assume for a moment that there is an election, and the probability of reelecting the incumbent is rising in the social welfare. Let $\operatorname{Pr}\{$ reelection $\}=P(W(a, t))$ with $P^{\prime}>0$ and $P^{\prime \prime}<0 . P(W(a, t))$ is therefore a measure of the "will of the voters."

However, the degree to which the will of the voters determines whether or not the incumbent returns to office depends on the regime type, and in particular on the degree to which the holder of office is bound by the interests of the electorate at large. Let $\Delta \in[0,1]$ be a measure of the degree to which the will of the voters is binding on the executive. This will be our measure of the polity's degree of electoral accountability, with $\Delta=1$ suggesting a pure democracy, where the will of the voters is perfectly reflected in the incumbent's probability of reelection. If instead $\Delta=0$, we have a pure autocracy, and the will of the voters is irrelevant to whether or not the incumbent survives in office. Then $\operatorname{Pr}\{$ survival $\}=\Delta P(W(a, t))+(1-\Delta)$. We have a continuous measure of the degree to which the executive is accountable to the voters' sentiments. The government is assumed to derive benefits $R$ from being retained in office, which occurs with probability $\operatorname{Pr}\{$ survival\}.

While the government benefits from improving electoral prospects by agreeing to sign a PTA or a BIT, it also sacrifices the ability to manipulate policy in response to unforeseen contingen- 
cies. International agreements (IAs) help to mitigate a commitment problem. Stochastic shocks to domestic interests may - absent a trade or investment agreement - induce greater lobbying for changes in policy (hence $\eta$ may be thought of as a realization of such shocks). Absent an IA, the government may give in to lobbyists' pressure following such a shock (Downs and Rocke 1995, Dixit 1996, Rosendorff 2005). The inability to respond to lobbyists' demands entails a cost for the government, at least in terms of sacrificed contributions or other political support.

We capture the government's choice between increasing policy stability and catering to political pressure in the following reduced form manner. The government experiences a trade-off when it comes to precision. As expressed above, more precision means greater social welfare. Voters and economic agents are better able to match their actions with the policy environment. But more precision comes at a cost to the leader. Leaders lose the discretion to adjust policy in support of special interests; they also lose the rents associated with the policies in question: tariff revenues for trade policy and/or tax revenues from high tax rates or even the value of expropriated FDI in the case of investment agreements.

However, the political costs of the reduced availability of rents differ across trade and investment agreements. And this difference is conditioned on regime type. The cost of precision is assumed to have the following form: $-\frac{1}{2}\left(\frac{k_{T}}{\sigma_{T}}+\frac{k_{I} \Delta^{2}}{\sigma_{I}}\right)$, with $k_{T}, k_{I}$ positive constants.

Recall that $\Delta$ runs from 0 (pure autocracy) to 1 (pure democracy). The specification says that the costs to an autocratic leader of signing a BIT are lower than for a democracy. This is the essential source of the paper's central thesis - democracies sign more PTAs but fewer BITs. The specification simply says that with more democracy comes more accountability, and hence fewer rents are available with which to buy political support or to payoff members of the winning coalition (Bueno de Mesquita et al. 2003). The specification emphasizes that increased accountability makes expropriation or discriminatory taxation more expensive; whereas tariffs generate revenue and rent that is less sensitive to political accountability or regime type.

Tariffs protect local firms, raise prices and shift factor prices. A PTA commits a government to refrain from redistributing income using this mechanism. Should a government do so however, it is not generally perceived as discriminatory, or subject to litigation in the courts as a violation of individual rights or the rule of law. Hence a more electorally accountable leader is not ceteris paribus any more disinclined to use tariffs than a leader less responsive to the electorate. When it comes to 
expropriation of fixed productive assets, or discriminatory taxation where a government taxes one firm at different rates than another, however, accountability does matter. A democratic leader can expect the rule of law to limit this behavior; an autocratic leader will not be limited as much. We model this by assuming the costs of expropriation of investment increase with democracy, whereas the (political) costs of raising tariffs is less affected by regime type.

The government's utility function is thus given by

$$
G(a, t, \alpha)=[\Delta P(W(a, t))+(1-\Delta)] R-\frac{1}{2}\left(k_{T} \alpha_{T}+k_{I} \alpha_{I} \Delta^{2}\right)
$$

and

$$
u_{i}\left(a_{i}, t\right)=-\sum_{p=T, I}\left(a_{i p}-t_{p}\right)^{2}
$$

with

$$
y_{p}=t_{p}+\eta_{p}, \eta_{p} \sim N\left(0, \frac{1}{\alpha_{p}}\right), p=T, I
$$

\section{PTAs, BITs and Uncertainty}

Consistent with the literature discussed above, we assume that PTAs and BITs increase the precision $\alpha_{p}$ or reduce the variance of the signals $\sigma_{p}$ for $p=I, T$. We assume that any PTA or BIT increases both $\alpha_{I}$ and $\alpha_{T}$, the precision of the signals. Moreover each agreement signed has a cumulative effect on overall precision of the signal. If $n_{p}$ PTAs or BITs are signed, the precision of the signal is $\alpha_{p}=\alpha\left(n_{p}\right)$ with $\alpha^{\prime}>0$, and $\alpha(0)>0$.

We have in mind the idea that an IA with one state reduces uncertainty with respect to the industries and issues demarcated in the agreement. When negotiating an agreement with a second state, additional sectors and/or industries become subject to the rules-based system.

The number of PTAs and BITs signed will be the choice variable for the executive.

Note that we do not model the explicit choice the government faces over the trade and investment policy, $t$. On the one hand, it doesn't really matter here what the policy is to the voters, as long as they can match their behavior to the policy environment. We have, therefore, abstracted away from the distributional consequences of policy. In order to keep the model simple and tractable, we set aside the game between competing groups over policy itself, and model the consequences of improved precision in the information flows over trade and investment policy. 


\section{The Game}

The voter will choose a pair of actions $a_{i}=\left(a_{i T}, a_{i I}\right)$; the executive will decide how many PTAs and BITs to sign, $n_{T}$ and $n_{I}$. Denote $n=\left(n_{T}, n_{I}\right)$. A Bayesian Nash equilibrium (Fudenberg and Tirole 1991) to this game is a pair of strategies $\left(a_{i}, n\right)$ such that the executive and any voter $i$ is playing a best response. The government, in choosing the number of PTAs and BITs to sign, is choosing an optimal level of precision that trades off the welfare gains to the voters (and hence enhanced survival probabilities) with the losses associated with the inability to use opaque practices for the benefit of the themselves or their cronies.

Consider the voter's problem. The voter receives signal $y$ and maximizes her expected utility:

$$
E u_{i}\left(a_{i}, t \mid y\right)=\sum_{p=T, I}\left[-a_{i p}^{2}+2 a_{i p} E\left(t_{p} \mid y_{p}\right)-E\left(t_{p}^{2} \mid y_{p}\right)\right]
$$

The first order conditions yields

$$
a_{i T}=E\left(t_{T} \mid y_{T}\right)=y_{T} \text { and } a_{i I}=E\left(t_{I} \mid y_{I}\right)=y_{I}
$$

\section{The executive's problem}

The executive maximizes $G(a, t, \alpha)$ given the voter's optimizing behavior $a_{i p}=y_{p}$ for $p=T, I$, and the fact that the voter will receive a stochastic signal distributed normally over the real line. Therefore after the signals have been sent, and the voters are simply setting their action as their signal, we can compute the equilibrium social welfare $W(a, t)=-\int \sum_{p=T, I}\left(a_{i p}-t_{p}\right)^{2} d i$. Given that $\left(a_{i p}-t_{p}\right)=\eta_{p}$ and that $\eta_{p}$ is distributed normally with mean zero and variance $\sigma_{p}$ (and the two signals have a zero covariance), it must be that $W(a, t)=-E\left(\eta_{T}^{2}+\eta_{I}^{2}\right)=-\left(\sigma_{T}+\sigma_{I}\right)=$ $-\left(\frac{1}{\alpha_{T}}+\frac{1}{\alpha_{I}}\right)$. Then $G(a, t, \alpha)=\left[\Delta P\left(-\frac{1}{\alpha_{T}}-\frac{1}{\alpha_{I}}\right)+(1-\Delta)\right] R-\frac{1}{2}\left(k_{T} \alpha_{T}+k_{I} \Delta^{2} \alpha_{I}\right)$.

Higher precision will mean a higher probability of reelection $P\left(-\sigma_{T}-\sigma_{I}\right)$ for the executive, since the expected value of the probability of reelection rises in the accuracy of the signal; but more precision means more losses for the executive, since they dislike precision, $-\frac{1}{2}\left(\frac{k_{T}}{\sigma_{T}}+\frac{k_{I} \Delta^{2}}{\sigma_{I}}\right)$.

Proposition 1. In any Bayesian Nash equilibrium, $\left(a_{i T}, a_{i I}, n\left(\sigma_{T}\right), n\left(\sigma_{I}\right)\right)$

$$
\frac{\sigma_{T}^{2}}{\sigma_{I}^{2}}=\frac{k_{T}}{k_{I} \Delta^{2}}
$$


The proofs are in the appendix. The voters make their best guess about the policy that is in effect, using the information provided by the public signal, and choose their actions based on that best guess. The government anticipates the voters' behavior, and chooses a level of policy uncertainty (by signing the optimal number of agreements) that balances their survival in office with their dislike of policy commitments. Overall the ratio of the variances chosen in equilibrium depends on the exogenous costs of rent dissipation $k_{T}$ and $k_{I}$ and on the level of democracy, $\Delta$. As $\Delta$ rises, the ratio of the variance of trade agreements falls relative to the variance on investment agreements. So the number of trade agreements rises relative to the number of investment agreements.

The key comparative static follows.

\section{Proposition 2.}

1. The equilibrium number of PTAs rises with $\Delta$, the degree of electoral accountability.

2. The equilibrium number of BITs falls with $\Delta$.

Enhanced democracy has two effects of the executive. On the one hand, there is greater need to provide policy transparency at the expense of opportunities for rent extraction. On the other hand, the value to the executive of diverted rents increases with democracy - those rents become more important when votes must be bought or campaigned for. The effective price of a (unit of precision due to a) PTA is fixed at $k_{T}$; the effective price of a (unit of precision due to a) BIT falls with autocracy. Hence more autocracy leads to the "purchase" of more BITs relative to PTAs; more democracy means fewer BITs relative to PTAs.

\section{Empirics}

We explore the empirical support for the theoretical observations in this section. This evidence is not offered as a comprehensive test of the theoretical claims. Rather the simple, suggestive model above is complemented with some broad evidence of empirical regularities.

\section{Data and Variables}

We consider 112 developing countries between the years of 1965 to 2004 . The level of analysis is the country-year and dependent variables are dummies, PTA and BIT, which are coded as 1 if a 
country had signed any number of PTAs or BITs in the current year, and zero otherwise (PTA data is drawn from Mansfield and Milner (2012), while BIT data comes from Tobin and Busch (2010)). The primary independent variable is the Polity score which measures the degree of democracy and it runs from 0 to 20. We use Polity as a proxy for the regime type (Marshall, Jaggers and Gurr 2000). A probit model is used to estimate the likelihood of countries signing an international commercial agreement in a given year.

We control for the usual covariates: trade as a percentage of GDP and logged population or logged GDP to proxy for market size in the PTA estimations. In the BITs estimation, we control for Foreign Direct Investment (FDI) as a percentage of GDP and for the cumulative number of PTAs already signed. ${ }^{2}$ Additionally, we control for economic variables such as GDP per capita, GDP per capita growth rate. The macroeconomic data comes from World Bank's World Development Indicators (WDI). We also include a time trend of signings in order to control for the systemic diffusion of these agreements over time. These trend variables are created by aggregating the signing behavior across countries and then generating the non-parametric trend variable over the years using lowess smoother method. Figure A.1 in Appendix shows that signing PTA was popular in 1960's but has slowed down since then, while signing BITs has become increasingly fashionable in recent years. Moreover in all models we control for region fixed effects (based on coding in Cheibub, Ghandi and Vreeland (2010)). There is usually a delay between the actual decision to sign and the official signing itself, so the polity score and all the other control variables are lagged in the estimations.

\section{Results}

Table 1 shows the result from the probit estimations. An increase in Polity increases the likelihood of PTA signing but decreases the likelihood of BIT signing. While Polity is statistically significant for both PTA and BIT models, the statistical significance of Polity is stronger for signing of PTAs compared to signing of BITs. Also the marginal effect of the change in Polity is larger for signing of PTAs compared to signing of BITs.

Increases in the share of Trade in GDP and market size proxies increases the likelihood of signing PTAs. Increases in the importance of FDI in the economy increases the likelihood of signing BITs. 
Also the more PTAs that a country has previously signed, the less likely it is to sign BITs. Among developing countries, poorer countries are more likely to sign international commercial agreements but economic growth only factors into investment treaties while market size affects signing of trade agreements.

Table 1: Signing International Commercial Agreements

\begin{tabular}{|c|c|c|c|c|}
\hline & PTA (1) & PTA (2) & BIT (1) & BIT (2) \\
\hline Polity & $\begin{array}{c}0.022^{* * *} \\
(0.006)\end{array}$ & $\begin{array}{c}0.022^{* * *} \\
(0.006)\end{array}$ & $\begin{array}{c}-0.012^{* *} \\
(0.005)\end{array}$ & $\begin{array}{c}-0.012^{* *} \\
(0.006)\end{array}$ \\
\hline Trade/GDP (Log) & $\begin{array}{c}0.379^{* * *} \\
(0.086)\end{array}$ & $\begin{array}{c}0.380^{* * *} \\
(0.086)\end{array}$ & & \\
\hline FDI/GDP & & & $\begin{array}{c}0.013^{* *} \\
(0.007)\end{array}$ & $\begin{array}{l}0.012^{*} \\
(0.007)\end{array}$ \\
\hline Population (Log) & $\begin{array}{c}0.149^{* * *} \\
(0.035)\end{array}$ & & & \\
\hline GDP (Log) & & $\begin{array}{c}0.149^{* * *} \\
(0.035)\end{array}$ & & \\
\hline Cumulative PTA & & & & $\begin{array}{c}-0.005^{* * *} \\
(0.002)\end{array}$ \\
\hline GDP per Capita (Log) & $\begin{array}{c}-0.168^{* * *} \\
(0.045)\end{array}$ & $\begin{array}{c}-0.317^{* * *} \\
(0.061)\end{array}$ & $\begin{array}{c}-0.075^{* *} \\
(0.036)\end{array}$ & $\begin{array}{c}-0.165^{* * *} \\
(0.038)\end{array}$ \\
\hline GDP per Capita Growth & $\begin{array}{l}-0.008 \\
(0.005)\end{array}$ & $\begin{array}{c}-0.008 \\
(0.005)\end{array}$ & $\begin{array}{l}0.011^{* *} \\
(0.005)\end{array}$ & $\begin{array}{l}0.012^{* *} \\
(0.005)\end{array}$ \\
\hline $\begin{array}{l}\text { Time Trend } \\
\text { (Lowess) }\end{array}$ & $\begin{array}{l}-1.344^{*} \\
(0.733)\end{array}$ & $\begin{array}{l}-1.342^{*} \\
(0.733)\end{array}$ & $\begin{array}{c}2.615^{* * *} \\
(0.156)\end{array}$ & $\begin{array}{c}3.091^{* * *} \\
(0.213)\end{array}$ \\
\hline$N$ & 2326 & 2326 & 2737 & 2669 \\
\hline
\end{tabular}

Using the predicted likelihoods from the models in Table 1, we ran two-sample t-tests ${ }^{3}$ splitting the observations into democracies and autocracies. Observations are separated by regime type using a regime type dummy drawn from Polity where a country is coded a democracy if Polity runs between 16 and 20, and autocracy if polity is less than 15 . We also use the DD regime dummy from Cheibub, Ghandi and Vreeland (2010) to split the sample.

While the correlation between the two regime type dummy variables are high, relatively more observations are coded as democracy when DD regime dummy is used. The mean likelihood of signing a PTA and a BIT are calculated for each group and a t-test is used to determine whether 
the mean difference between two groups is statistically significantly different from zero. As expected, for both the likelihoods of signing PTA and BIT, mean differences between democracies and autocracies are highly significant.

For the likelihood of signing a PTA, the mean likelihood of democracies is about 22.4 to 23.5 percent and 19.5 to 19.8 percent for autocracies. The estimated mean difference is 2.6 to 3.9 percent and democracies are more likely to sign PTA compared to autocracies. On the other hand, democracies are less likely to sign a BIT compared to autocracies, given the mean difference of $3.7-5.4$ percent. The mean likelihood of signing BIT for democracies is about 67.0 to 68.1 percent and is about 62.7 to 63.3 percent for autocracies.

Figure 1 shows the marginal effect of Polity on the predicted likelihood of signing a PTA or a BIT by a country in a given year. Fitted lines show that as the polity score increases, the likelihood of PTA signing increases while likelihood of BIT signing decreases. While strongly autocratic countries with very low polity scores only signs PTAs with average likelihood of about 17 to 18 percent, strongly democratic countries with very high polity scores sign PTAs with average likelihood of about 24 to 25 percent. We see the significant difference between two regime types in terms of signing of PTAs. Although the relationship between polity and signing of BIT is not as clear and the effect is comparatively smaller to that of PTA signing, we still see decreasing marginal effect of polity score on the likelihood of signing BITs. 
Figure 1: Predicted Likelihood of Signing International Commercial Agreements and Polity Score
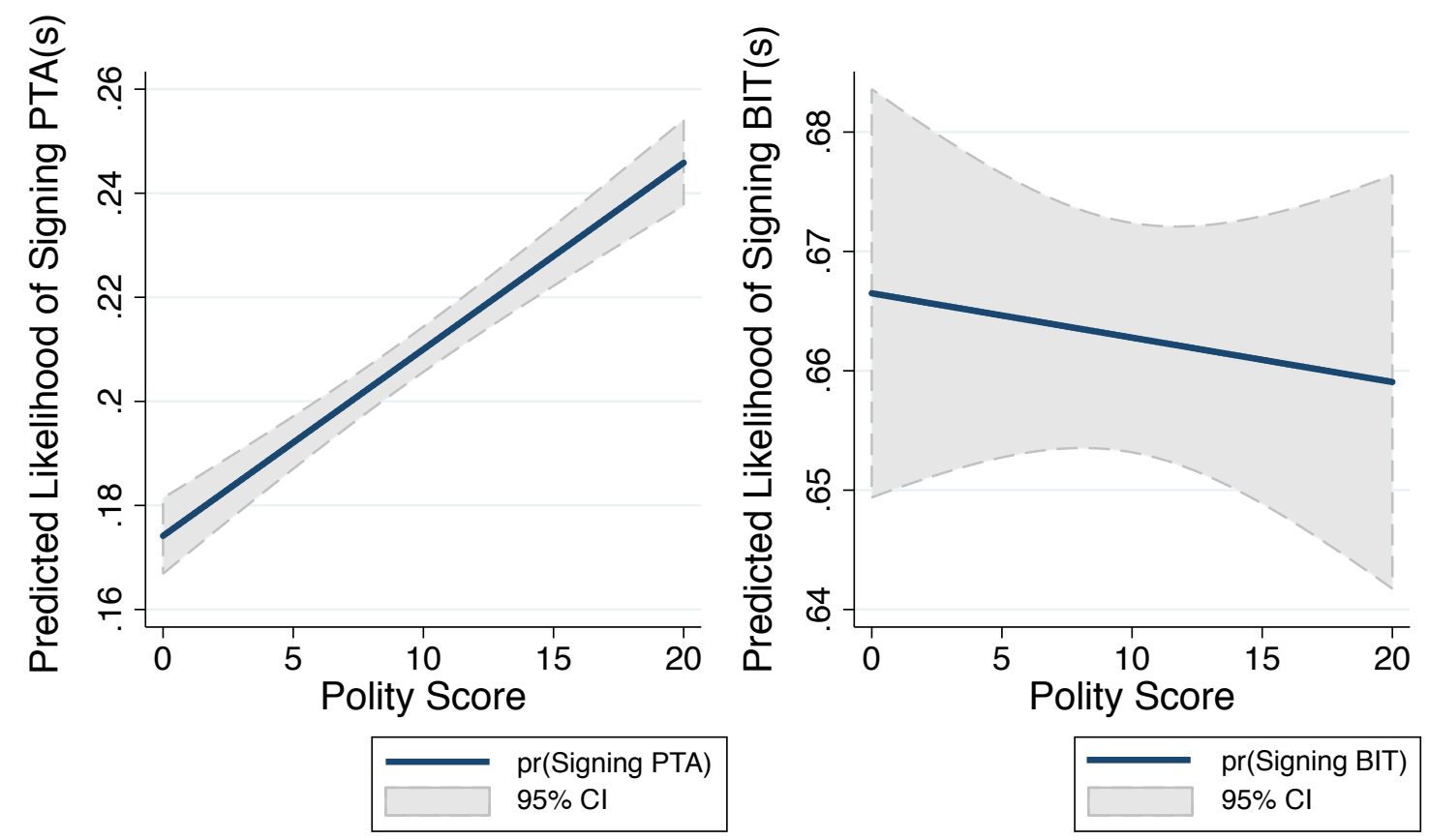

\section{Conclusion}

This short article offers an unexpected finding. While it has become accepted wisdom that democratic polities are more cooperative internationally, and this is especially true of international trade agreements, this paper shows that the prevailing wisdom may not apply to bilateral investment treaties. In fact, it appears that non-democracies are systematically more likely to accede to an investment treaty than are democracies in the developing world.

There are many potential reasons for this finding. The model presented here offers one reason, based on the transparency-enhancing features of these international agreements. Executives benefit electorally when transparency is enhanced - resources are better allocated which enhances social welfare. But they forgo opportunities for rent extraction, perhaps via lobbying contributions, or outright corruption. A PTA restricts the availability of tariff revenue rents that might have been used to bolster political support. A BIT also restricts rents - reduces the possibility of discriminatory taxation or expropriation. If, as we argue here, regime type has little effect on the tariff revenues and rents, but democracy makes expropriating investors more costly, then a rational executive faces 
the opportunity to substitute between PTAs and BITS according to the relative costs associated with the rents forgone. An autocratic leader finds that the costs of expropriating investment are relatively low will therefore sign more BITs and fewer PTAs; a democratic leader facing relatively higher "price" of BITs signs fewer of them, and substitutes towards PTAs.

There are of course other explanations consistent with this observed regularity. Autocratic states have much to gain from FDI, but their promises of low taxes are not credible. A BIT offers more credibility to the promise, and hence it is the more autocratic states that sign more BITs; democratic states' promises not to raise tariffs and spur a trade war with their trading partners are more reliable, and hence a trade agreement with a democracy is more likely to be effective than with an autocracy. Democracies' promises to comply with an agreement are more credible because of multiple veto players make policy change difficult; audience costs make promises expensive to renege upon; reputations are more valuable and many other reasons.

Whatever the precise reason, and it is likely a combination of these, the theory and the data suggest this very interesting, and surprising (from the point of view of the received wisdom) finding that the effect of regime type on international commercial cooperation depends on the types of flows the agreements govern. Goods and services agreements are more likely among democracies; autocracies are more likely to sign investment treaties.

The essential assumption driving the result is that the shadow price of rents rises with democracy when those rents have expropriation or taxation of investment as their source, whereas the the shadow price of rents that emerge from tariff revenue does not change with regime type. While this is a strong assumption, what is important is that the difference in the shadow prices of investmentsourced relative to trade-sourced rents rises with democracy. This seems reasonable - democracies with the rule of law, independent judiciaries, and separation of powers all make expropriation less likely, but doesn't change the propensity of governments to make use of available tariff overhang or otherwise use legal trade-policy instruments.

This approach has also focussed on the role IAs play in reducing policy uncertainty, improving the flow of market-relevant information, and hence their role in improving social welfare. Of course IAs may enhance social welfare for other reasons - increasing the volume of trade and investment, for instance. The central results of this model continue to hold as long as IAs enhance social welfare on the one hand, and reduce rent creation in the way described. 
These results should be interpreted with appropriate caution. This is not a general theory of IA accession. We have focussed on the role PTAs and BITs play in coordinating expectations. Other mechanisms may be operative: as we have argued, IAs limit the levels of punitive barriers, perhaps enhancing leadership survival in democracies; or a IAs may simply be a signal of the leader's competence, and voters may simply be rewarding competence. Ideally, we would develop empirical tests to distinguish these possible mechanisms. Obtaining data on leader competence, extractive behavior or policy uncertainty across time and countries is of course tricky - these are fundamentally unobservable, and existing data is not reliable.

The effect of regime type on participation may vary across other types of international institutions. This is true especially for those that provide information to domestic audiences regarding the future policy decisions of the government. The incentives to enter into such an agreement will be determined, in part, by domestic political institutions. Higher levels of democracy lead, ceteris paribus, to greater incentives to boost citizen welfare. As such, democracies have a stronger rationale for entering into some international agreements with the aim of reducing policy uncertainty, but lower incentives for entering into others when that reduction in uncertainty excessively reduces the opportunity for rent extraction, even within democracies.

\section{Notes}

1. A brief summary can be found in Hollyer and Rosendorff (2012).

2. Many PTAs contain investment clauses which already specify agreements regarding inter-country investment. Therefore we expect that the countries which already have signed large number of PTAs is less likely to sign BITs separately.

3. We used a t-test with unequal variances - democratic and autocratic subgroups are not assumed to have equal variances.

\section{References}

Allee, Todd and Clint Peinhardt. 2014. "Evaluating three explanations for the design of Bilateral Investment Treaties." World Politics 66(1):47-87. 
Arias, Eric, James R. Hollyer and B. Peter Rosendorff. 2014. "Leader Survival, Regime Type and Bilateral Investment Treaties.” Unpublished, New York University .

Bueno de Mesquita, Bruce, Alastair Smith, Randolph Siverson and James D. Morrow. 2003. The Logic of Political Survival. Cambridge, MA: MIT Press.

Cheibub, Jose Antonio, Jennifer Ghandi and James Raymond Vreeland. 2010. "Democracy and Dictatorship Revisited." Public Choice 143(1-2):67-101.

Dixit, Avinash. 1996. The Making of Economic Policy: A Transactions-Cost Politics Perspective. Cambridge: MIT Press.

Downs, George W. and David M. Rocke. 1995. Optimal Imperfection? Domestic Uncertainty and Institutions in International Relations. Princeton, NJ: Princeton University Press.

Elkins, Zachary, Andrew T. Guzman and Beth A. Simmons. 2006. "Competing for Captial." International Organization 60:811-846.

Fudenberg, Drew and Jean Tirole. 1991. Game Theory. Cambridge, MA: The MIT Press.

Hollyer, James R. and B. Peter Rosendorff. 2012. "Leadership Survival, Regime Type, Policy Uncertainty and PTA Accession." International Studies Quarterly 56(4):748-764.

URL: $h t t p: / / d x . d o i . o r g / 10.1111 / j .1468-2478.2012 .00750 . x$

Mansfield, Edward D. and Helen V. Milner. 2012. Votes, Vetoes, and the Political Economy of International trade Agreements. Cambridge University Press.

Mansfield, Edward D., Helen V. Milner and B. Peter Rosendorff. 2000. "Free to Trade: Democracies, Autocracies and International Trade." American Political Science Review 94(2):305-322.

Marshall, Monty G., Keith Jaggers and Tedd Robert Gurr. 2000. "Polity IV Project: Political Regime Characteristics and Transitions, 1800-1999." Available at http://www.systemicpeace.org/polity/polity4. (Accessed July 1, 2012).

URL: http://www.systemicpeace.org/polity/polity4

Milner, Helen V. and B. Peter Rosendorff. 1996. "Trade Negotiations, Information and Domestic Politics: The Role of Domestic Groups.” Economics and Politics 8(2):145-189. 
Milner, Helen V. and B. Peter Rosendorff. 1997. "Democratic Politics and International Trade Negotiations: Elections and Divided Government as Constraints on Trade Liberalization." Journal of Conflict Resolution 41(1):117-147.

Pahre, Robert. 2008. Politics and Trade Cooperation in the Nineteenth Century: the "Agreeable Customs. New York: Cambridge University Press.

Pevehouse, Jon C., Emilie Hafner-Burton and Matthew Zierler. 2002. "Regional Trade and Institutional Design: Long After Hegemony?" Unpublished, University of Wisconsin. Presented at the 2002 MPSA Meetings.

Rosendorff, B. Peter. 2005. “Stability and Rigidity: Politics and the Design of the WTO's Dispute Resolution Procedure." The American Political Science Review 99(3):389-400.

Rosendorff, B. Peter and Kongjoo Shin. 2014. "Regime Type and International Commercial Agreements." Unpublished, New York University .

Salacuse, Jeswald W. and Nicholas P. Sullivan. 2005. "Do BITs really work? An evaluation of bilateral investment treaties and their grand bargain." Harvard International Law Journal 46(1):67130.

Tobin, Jennifer L. and Marc L. Busch. 2010. "A BIT is Better Than a Lot: Bilateral Investment Treaties and Preferential Trade Agreements." World Politics 62(1):1-42.

Yano, Makoto. 1989. "Voluntary Export Restraints and Expectations: An Analysis of Export Quotas in Oligopolistic Markets.” International Economic Review 30(4):707-723. 


\section{Appendix 1: Proofs}

\section{Proof of Proposition 1}

Recall $W(a, t)=-\int \sum_{p=T, I}\left(a_{i p}-t_{p}\right)^{2} d i$. Now each individual's best response is $a_{i p}=y_{i p}, p=$ $I, T, \forall i$, and $y_{i p}-t_{p}=\eta_{p}\left(0, \frac{1}{\alpha_{p}}\right)$. Then

$$
\begin{aligned}
W(a, t) & =-\int \sum_{p=T, I} \eta_{p}^{2} d i \\
& =-\int_{T} \int_{I}\left(\eta_{T}^{2}+\eta_{I}^{2}\right) \frac{\sqrt{\alpha_{T} \alpha_{I}}}{\sqrt{2 \pi}} e^{-\frac{1}{2} \alpha_{T} \eta_{T}^{2}} e^{-\frac{1}{2} \alpha_{I} \eta_{I}^{2}} d \eta_{T} d \eta_{I} \\
& =-\left(\sigma_{T}+\sigma_{I}\right)
\end{aligned}
$$

Then $(G(a, t, \alpha) \mid t)=\left[\Delta P\left(-\sigma_{T}-\sigma_{I}\right)+(1-\Delta)\right] R-\frac{1}{2}\left(\frac{k_{T}}{\sigma_{T}}+\frac{k_{I} \Delta^{2}}{\sigma_{I}}\right)$

Maximizing over $\sigma_{p}, p=I, T$

$$
\begin{aligned}
\frac{\partial}{\partial \sigma_{T}} G(a, t) & =-\Delta P^{\prime}+k_{T} / \sigma_{T}^{2}=0 \\
\frac{\partial}{\partial \sigma_{I}} G(a, t) & =-P^{\prime}+k_{I} \Delta / \sigma_{I}^{2}=0
\end{aligned}
$$

Together these imply $\frac{\sigma_{T}^{2}}{\sigma_{I}^{2}}=\frac{k_{T}}{k_{I} \Delta^{2}}$

Proof of Proposition 2

By Cramers' rule,

$$
\frac{d \sigma_{T}}{d \Delta}=\frac{G_{T I} G_{I \Delta}-G_{T \Delta} G_{I I}}{G_{I I} G_{T T}-G_{T I} G_{I T}}
$$

Denominator is positive by the second order condition. Consider the numerator

$$
\Delta P^{\prime \prime} k_{I} / \sigma_{I}^{2}+P^{\prime}\left(P^{\prime \prime}-2 k_{I} \Delta / \sigma_{I}^{3}\right)<0
$$

Since $P^{\prime \prime}<0$. So $\frac{d \sigma_{T}}{d \Delta}<0$ and $\frac{d N_{T}}{d \Delta}>0$. Similarly by Cramers' rule,

$$
\frac{d \sigma_{I}}{d \Delta}=\frac{G_{I T} G_{T \Delta}-G_{I \Delta} G_{T T}}{G_{I I} G_{T T}-G_{T I} G_{I T}}
$$

As before, the denominator is positive by the second order condition. Consider the numerator

$$
P^{\prime \prime}-k_{I} / \sigma_{I}^{2}\left(P^{\prime \prime}-2 k_{T} / \sigma_{T}^{3}\right)>0
$$

As before, $P^{\prime \prime}<0$. Hence $\frac{d \sigma_{I}}{d \Delta}>0$ and $\frac{d N_{I}}{d \Delta}<0$. 


\section{Appendix 2: Summary Statistics and Time Trends}

Table A.1: Summary Statistics

\begin{tabular}{lcccc}
\hline \hline Variables & Mean & Std. Error & Min & Max \\
\hline Year & & & 1965 & 2004 \\
PTA Dummy & 0.32 & 0.47 & 0.00 & 1.00 \\
Cumulative PTAs & 19.74 & 24.72 & 0.00 & 118.00 \\
BIT Dummy & 0.47 & 0.50 & 0.00 & 1.00 \\
Polity & 8.44 & 6.71 & 0.00 & 20.00 \\
Trade/GDP (\%) & 64.04 & 43.61 & 6.32 & 439.03 \\
FDI/GDP (\%) & 2.24 & 6.22 & -82.89 & 145.20 \\
Population & $3.05 \mathrm{e}+07$ & $1.17 \mathrm{e}+08$ & $6.36 \mathrm{e}+04$ & $1.30 \mathrm{e}+09$ \\
GDP & $3.70 \mathrm{e}+10$ & $1.03 \mathrm{e}+11$ & $10.0 \mathrm{e}+07$ & $1.72 \mathrm{e}+12$ \\
GDP per Capita & 1752 & 2549 & 62.24 & 25651 \\
GDP per Capita Growth & 2.26 & 42.70 & -50.05 & 2655.88 \\
\hline \hline
\end{tabular}

Country-Year observations for 112 developing countries. Cumulative numbers of commercial agreements are for each country in a given year. GDP, GDP per Capita in constant 2000 U.S dollars. 
Figure A.1: Time Trend of Signing International Commercial Agreements
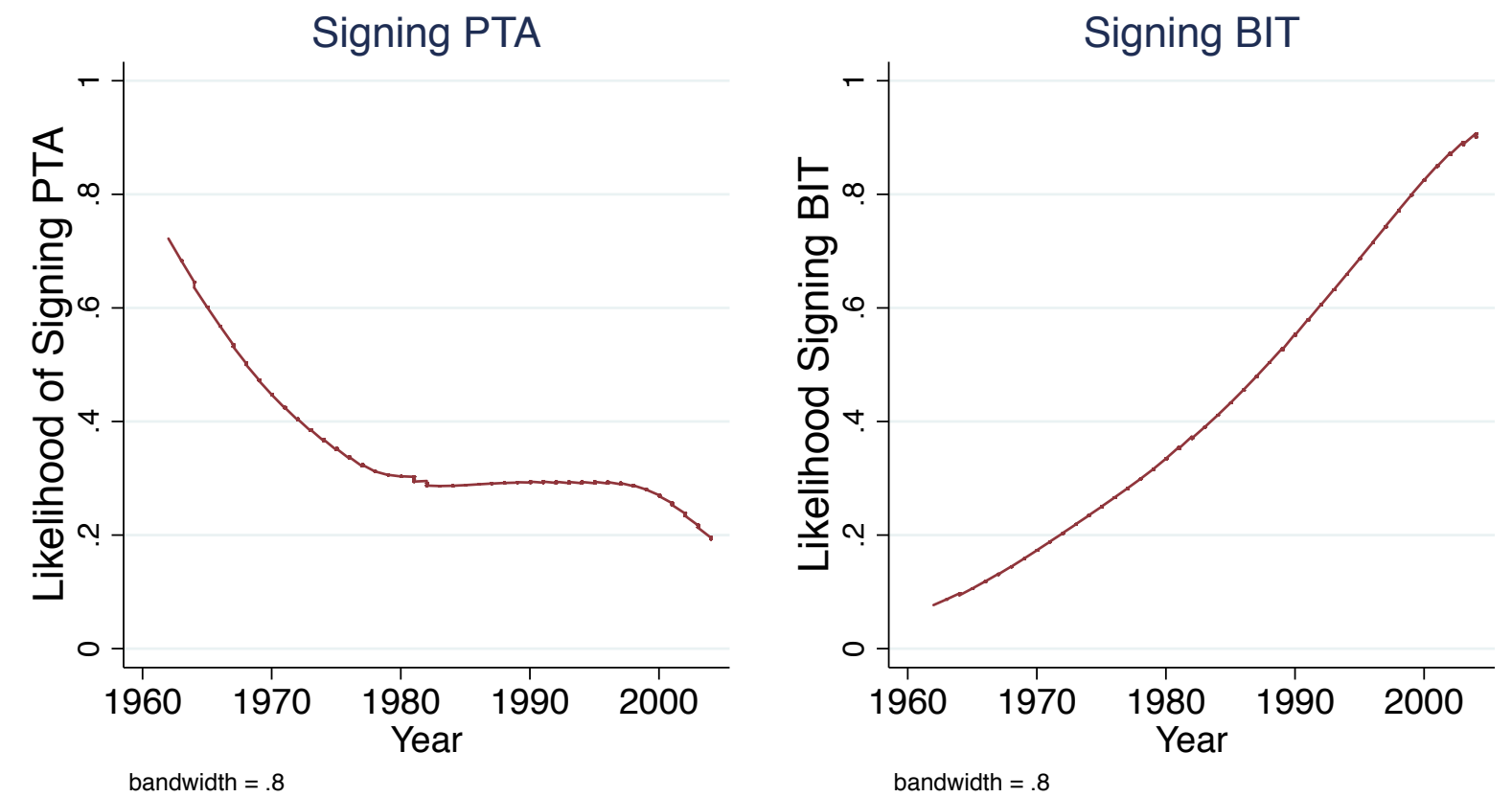